\title{
The Use of Mobile Communication in the Marketing of Foodstuffs in Côte d'Ivoire
}

\author{
Kabran Aristide Djane and Richard Ling
}

This paper examines the use and non-use of mobile communication in the food distribution system of Côte d'Ivoire. We examine how this mediation forms in the existing systems for producing, transporting and marketing of food by women in that country. We base the analysis on five focus groups and 51 interviews carried out between May 2012 and February 2013. We find that mobile communication allows for more responsive and flexible planning on the part of large- and small-scale wholesalers. They are able to use it to manage and adjust the delivery of products to different retailers as surpluses and shortages develop. We also find that the mobile phone is not used by some producers since there are well-established systems for the marketing of their products that preclude the need for mobile communication.

\section{Introduction}

A food market in Côte d'Ivoire is a seeming welter of sounds, sights and odours. To an uninformed visitor, the whole can seem overwhelming. The market consists of many small stalls where women are hawking different foodstuffs. Around the perimeter, there may be buildings with cloth stores, hardware stores and the like. Large trucks move about, and bags of food are loaded and unloaded while shoppers

\footnotetext{
K.A. Djane $(\bowtie)$

Université de Korhogo, Korhogo, Côte d'Ivoire

e-mail: aristide.djane@upgc.edu.ci

R. Ling

Division of Communication Research, Wee Kim Wee School for Communication and Information College of Humanities, Arts, \& Social Sciences, Nanyang Technological University,

Singapore, Singapore

e-mail: rili@ntu.edu.sg

A. Chib et al. (eds.), Impact of Information Society Research in the Global South, DOI 10.1007/978-981-287-381-1_12 
move about looking at the different offerings and making their purchases. In one stall there might be tomatoes and in another live snails. On the edge of the market, there may be a small group of elderly women who are keeping a careful watch over the situation. Indeed, these women are often the central actors in the organization of these large-scale markets.

While it may seem chaotic, there are well-entrenched routines and ways of organizing the production, transport and marketing of the wares. There are flows of wares, information and monies that have been developed over time. In some cases, these are being changed by the adoption of mobile communication, but our work suggests that in other cases, this type of mediated interaction is not widely accepted and utilized for this purpose.

A central idea motivating this work is that improving information flow in the value chain supports development. If the information contained in this value chain is easily accessible by the players, it will facilitate market logistics. Abraham (2006), also echoed in the work by Rashid and Elder (2009), suggests a strong link between mobile phone access and increased economic opportunities for farmers. Among other things, these authors note the increased ability on the part of the producers to follow price information, hence allowing them to better judge when to sell their crops.

In this chapter, we will first examine the role of mobile communication for marketing in developing countries. We will then review this in terms of marketing foodstuffs. Following a discussion of the methods, we will look at the role of mobile communication in the case of large-scale wholesaling, smaller "petite" wholesalers and producers who do not find the mobile phone useful. In conclusion, we will offer some comments on the broad effect of mobile communication in the marketing of food in Côte d'Ivoire.

\section{Literature Review}

\subsection{Distribution of Food Products in African Countries: A Food Security Problem}

Turning to the question of food production in Africa, for nearly 20 years (1970 1989), the dominant issue in discussions on food consumption in African cities has been the supply to the city by the countryside. The 1950s saw the push to develop cash crops that disrupted the domestic production of foodstuffs. From the mid1990s, however, there has been a renewed interest by, for example, the Food and Agriculture Organization (FAO) of the United Nations to supply the cities in Africa with domestic foodstuffs (FAO 1996). The change in approach coincides with the urban explosion. The push has been in response to the growing demand for food in urban areas by developing domestic production. This implies reduced dependence on imports and a focus on least cost routing of commodities. This approach also has 
the potential to create jobs, but it becomes more complex when one considers the relationship between urbanization, poverty and food insecurity (Molony 2006).

Earlier studies have been devoted to the food supply of large cities in Africa. These include Goossens et al. (1994) who examined the system in Kinshasa and Chaléard (1996) who studied Abidjan and Bouake in Côte d'Ivoire. According to Argenti (1997), there is the need to give "priority to improving the efficiency of marketing systems and links between areas of production and consumption, to facilitate access to food and thus improve food security". When thinking of these production and marketing systems, the food supply and distribution involve several spatial scales: first, there is the suburban or rural areas in which there is the production and collection of food products; second, there is the intervening logistical space of exchange and redistribution from the rural collection to the urban markets; and finally, there is the city as a location of final consumption. If it is suggested that supplying urban centres with food is an opportunity for rural producers, this depends on efficient connections between the production, processing and storage areas via the transport system into the markets of the city. According to Courade (1985), urban-based demand will be an engine of change provided that the agricultural supply chains and transport are efficient and transaction costs are as low as possible.

\subsection{Mobile Communication and the Logistics of Food Marketing}

The mobile phone has been widely adopted in developing countries in the past decade (Donner 2008). A major effect of the mobile phone is that it has been used by impoverished people to change their life situation (Souter et al. 2005), and it has affected the way that food production has taken place (Jensen 2007). Flor (2009) sees the institutionalization of the so-called e-agriculture as an important instrument with which to address agricultural problems. Following the work of Flor, an analysis by the World Bank (2012) examines how mobile telephony can strengthen access to agricultural information and provide access to new markets. Porter (2012) who examines sub-Saharan Africa and Beuermann et al. (2012) who study Peru also confirm this economically based approach examining the effect of mobile telephony on community wellbeing. They found that mobile phone coverage increases the income, assets and expenditures of rural consumers.

Mobile communication gives people access to time-sensitive information that can be used in commercial settings to facilitate the functioning of markets. This finding is not new. For example, Fischer (1992) discusses how farmers in the USA used the landline telephone to follow the ebbs and flows of crop pricing. This allowed them to consider when to hold and when to sell their crops by allowing for the diffusion of pricing information and the relative excess or shortage of crops at different points in time. The landline has also been used in developing countries for these purposes (Clark 1995) albeit the lack of access meant it was not a commonly used tool. The mobile phone has changed people's lifestyle and habits in the developing world. 
Indeed, there are more mobile phones in developing countries than in the developed world. While our research shows that the functionality is not universally adopted, we are able to see the contours of when and how it has been seen as useful.

The analysis in Côte d'Ivoire enters into a series of studies that look at the use of mobile communication in marketing in developing countries. In general, research points to the way in which mobile communication reduces the costs and time required for commercial activities (Jagun et al. 2008; Overå 2006). The work of Jagun et al. (2008) documents changes in the logistics associated with cloth production in Nigeria. The mobile phone allowed the substitution of phone calls for journeys. The ability to make this substitution, however, rested upon the mutual trust between the interlocutors and necessary training farmers and the use of mobile phones for accessing innovations on agriculture.

Time saved per call was typically several hours, and, overall, this had meant that the turnaround time between the first order and final fulfilment was reduced. Money saved was typically understood by comparing call costs with transport costs: for example, interviewees talked about a call rate of N50 (ca. USD 0.40) per minute being cheaper than a taxi cost for an average journey of, say, N1,000 (ca. USD 8.00), given that calls were normally completed in less than 5 min (Jagun et al. 2008: p. 57).

There was still the need for travel and transport in this system, but the mobile phone streamlined this need. People who had a legacy of interaction and who were embedded in a network of both trust and mutual obligation used the mobile phone to facilitate the commercial process. They summarized by saying that, "in conceptual terms, this study confirms the need to understand mobile phones as devices for communication of information" (Jagun et al. 2008: p. 60). The communication of information as a way to facilitate the flux of commercial interactions is a theme that runs through the literature on mobile communication in these contexts.

The same theme is seen in the work of Robert Jensen in what is perhaps the most exhaustive studies of mobile communication's role in foodstuff production in developing countries (Jensen 2007). Jensen was interested in the effect of market information on the pricing of fish in Kerala, India. He was able to gather the spot price of fish every day for approximately 5 years for 15 different "beach markets" where boats sold their catch. Jensen's period of data collection covered the time in which mobile phones were introduced into this area. Thus, his work studied the effect of access to more timely and ubiquitous market information. Prior to the adoption of mobile phones, the boats would return to their homeport with their daily catch. Following the notion of supply and demand, if there was a good catch by the fleet for a particular port, the price of fish would be low and vice versa. In scenarios where late-coming boats could not sell their fish, the catch would be dumped into the harbour. Yet, it is likely that at a neighbouring port, there would not be enough fish to meet demand. Thus, the lack of information meant that there was not an optimal distribution of the fish.

The analysis of Jensen dramatically illustrates how the advent of mobile communication changed this situation. After buying mobile phones, the boats could call up the ports and compare the prices of fish. If they could realize a better price at 
another market instead of their homeport, they were able to act on this information. Jensen's material shows that on any given day, between 30 and $40 \%$ of all boats delivered their fish to markets outside their homeport. Over time, the price of fish stabilized and dumping of fish totally ceased. According to Jensen:

We find that the addition of mobile phones reduced price dispersion and waste and increased
fishermen's profits and consumer welfare. These results demonstrate the importance of
information for the functioning of markets and the value of well functioning markets;
information makes markets work, and markets improve welfare (Jensen 2007: p. 919).

Jensen also makes the point that facilitating the flow of information via the use of mobile communication was not a traditional development project. Rather, it was the diffusion of technology in a situation where there was a convergence among various commercial actors. Both Abraham (2006) who also examines the same production chain and Aker (2008) who studies the effect of mobile phones in Nigerian grain production note that mobile communication increases the market efficiency and reduces risk and uncertainty.

While the work of Jensen points to the potential for enhanced information flow, there are limitations. For one, there is not a system for storing the fish for more than a few hours after being caught. This means that the flow of information is particularly useful in this case since the producers and the consumers both benefit from expediting the process. There are likely similar possibilities with products such as milk, eggs, fruit, vegetables and spot-labour markets (Jensen 2007: p. 920). In addition, the market studied by Jensen has a large number of actors. There are no cartels or major actors who exert disproportionate influence.

The work of Barrantes Cáceres and Fernandez-Ardevol (2012), in their study of market traders in Peru, corroborates that of Jensen on several points. Their work takes the perspective of the individual entrepreneur having wares to sell at the weekly markets in rural Peru. Echoing Jensen, they describe how these actors poll other sellers in order to seek out the best weekly markets to attend, given that they have several alternatives to choose from. They find that the traders who deal in perishable commodities and have more to lose by not actively participating in the markets were more likely to use mobile phones for such purpose. It is interesting to note that there are some traders in this system that did not particularly benefit from using the mobile phone, namely, those who did not deal in perishable commodities and those who were more buffered from the immediate need to participate.

Rahman (2007) examines how pricing of foodstuffs that can be stored (such as rice) do not necessarily follow the same dynamics as noted by Jensen. In this case, poor farmers who need to repay loans can be forced to sell even when the price is low. Rahman notes that in contrast to "ideal-type" markets, the daily situation faced by farmers can be characterized by diverse cross-cutting formal and informal institutions, where the access to information noted by Jensen does not necessarily have the same effect.

There is a legacy of work showing that mobile communication facilitates the trading and commerce in developing countries. As noted by Overå in her analysis of the mobile phone use in Ghana, the device is a tool that facilitates information 
exchange and can be used to cultivate reliability in various marketing chains. In the same spirit, Prahalad and Hammond (2002) notes that mobile telephony gives economic actors access to information regardless of their position in the income pyramid. As such, it helps in the distribution of wares, particularly when there are gluts or shortages of perishable commodities. In summary, the mobile communication facilitates the flow of information allowing actors in some situations to better orientate themselves to the ebbs and flows of the market.

\subsection{Barriers to Mobile Phone Use}

While there are many possibilities associated with the adoption of mobile communication, it is important to point out that there are also barriers. One point is that ownership of a mobile phone can disturb gendered ideas regarding power (Chib and Hsueh-Hua Chen 2011) and notions of propriety (Cohen et al. 2007). Another is that there is a long tradition of oral interaction (Barrantes Cáceres and FernandezArdevol 2012). The mobile phone contravenes traditional ways of interacting. The oral tradition is a well-established mode of knowledge transmission between various castes in Africa. While this is evolving in African matriarchal societies, as is the case in most traditional societies, the family's secret knowledge is owned by women. The woman is, in the eyes of African society, the foundation of the family. The balance of the family rests on this outlook.

Moreover, the mobile phone is sometimes treated with suspicion. In some situations, the mobile phone carries with it certain taboo. The issue of myths and fears associated with the use of mobile phones is a recurring theme in the research. In their work in South America, Fernández-Ardèvol et al. (2011) note that the question of mobile-based myth and taboo is linked to the perception of in-group versus out-group and even can be seen as an invention of the devil. Similarly, in some sub-Saharan countries, the mobile phone is seen as the tool of sorcerers and other "marabouts" who use it to locate their enemies and cast spells on them from a distance. The spell can be received just by picking up the phone. These perceptions are common in rural areas but less so in the cities (Gakuru et al. 2009). ${ }^{1}$ These negative understandings of the mobile phone in rural areas can hinder its use in the agricultural value chain.

\subsection{Women, Food Production and Mobile Telephony}

In many West African countries, women play a central role in the production and marketing of foodstuffs. In Ghana, for example, there is the ohemma

\footnotetext{
${ }^{1}$ This difference indicates that these unfavourable perceptions of the mobile phone can eventually be changed through the use of education (Sauvé and Machabée 2000).
} 
(or the Queen Mothers) (Overå 2006), and as we will see below, Côte d'Ivoire has the tradition of the "Chain of the Grandmother". Each case study describes a system whereby women are the key actors in the production, transportation and sale of foodstuffs. This does not mean that they do the lower-level work and men are in charge of wholesale functions. Rather, it is women who are active at all levels. According to Overa (2006), these women are the negotiators when it comes to conflicts; they interact with authorities, organize the marketing chain and administer the marketing areas. To be sure, there are men who, for example, drive the trucks, help with the loading and unloading and help to organize the marketplace. However, it is women who sit in central positions of authority. ${ }^{2}$

Work by Hafkin and Odame (2007) outlines how women have a central role in the preservation of food security. As such, the women are an essential element in the social structure. This means that women's use of mobile commutation can be a major linchpin in the resolution of social issues. Their mastery of the technology affords social benefits (Johnson 2004). Especially in the development of new practices, intended crops reduce the level of food insecurity. Rural women who engage in agricultural become a hub through which many partners communicate via the mobile phone. The assertion of Souter et al. (2005) is echoed in the work of Fernández-Ardèvol et al. (2011), namely, that there is an important role for the mobile phone in the social relationships between the actors in a female-based agricultural system.

In this context, the mobile phone has helped to change the situation of women (Bayes 2001). Research has shown that the mobile phone is an important tool for women farmers. In Uganda, for example, the use of mobile phones enables rural women to increase their income by better following market developments. Dimitra found that there was a link between poverty reduction and ICT use among women (Asenso-Okyere and Mekonnen 2012). ${ }^{3}$

In the case of Côte d'Ivoire, an important element in the logistics of food distribution between producer and retailer is the so-called Chain of the Grandmother. This draws on use of well-entrenched traditional symbols to facilitate the distribution process. The existence of this augurs against use of electronic mediation.

In addition to celebrating the legacy between generations, it is also useful since it allows the women, who are largely illiterate, to organize a complex distribution system. When a buyer in the countryside secures produce for a retailer in the city, they negotiate a price and then mark the bags of produce with a piece fabric that has the individual pattern of the retailer. This piece of cloth, with a unique colour and pattern, allows the truck driver to route the produce to the correct women in the city. The truck driver becomes the instrument of communication in this case between the buyer and the producer. The system relies heavily on interpersonal "mouth-to-ear" interactions. Even though the majority of respondents consider that this approach is

\footnotetext{
${ }^{2} \mathrm{http}: / /$ www.irinnews.org/report/92213/cote-d-ivoire-women-bring-food-to-market-against-allodds

${ }^{3}$ See also http://www.fao.org/dimitra/home/en/
} 
quite difficult when determining the scheduling and pricing of wares, the physical contact has the advantage of maintaining trust between stakeholders in the food distribution business.

The marketing of food products Côte d'Ivoire has some elements of a cartel. There is one ethnic, the "Gouro", who dominates in this system. Because of the structural adjustment programme of 1983, many Gouro men lost their jobs. This meant that in order to take care of their family, women were obliged to work. They started working with producers in different Ivorian villages and organized cooperatives and provided them with seeds and fertilizer. They were able to secure locations within the cities, interact with drivers and set up wholesale operations with drivers, wholesalers and retailers within the different market spaces.

Coming back to our general research theme, the research question that drives the analysis is to study if "rural women will use the mobile phone in food production and distribution if they perceive mobile phone to be a tool that improves the distribution of their food products and it also improves their revenue stream". In the sections below, we will examine various stakeholders' understandings of the mobile phone. We will particularly focus on the role of the phone vis-à-vis food production, transportation and marketing.

\section{Methods and Data}

We drew on qualitative data to examine the role of mobile communication in food production, distribution and marketing based on the situation in Côte d'Ivoire. Our research draws on a series of field investigations conducted from May 2012 to February 2013, in the department of Soubré and Korhogo in Côte d'Ivoire. Each site was visited three times.

Soubré is a town in southwestern Côte d'Ivoire. The inhabitants of the department of Soubré are from the Kru group. ${ }^{4}$ Soubré is an important agricultural area that produces some of the best quality cocoa and coffee. Our reason for choosing this area was that it would give us insight into an area that has an active and lucrative agricultural sector. The sites or villages that were visited during the fieldwork in this region included the town of Soubré as well as Koreyo I, Logboayo, Sokozoua and Oureyo.

Korhogo is a town in northern Côte d'Ivoire. It is the capital of the savannah region of the country. It is also the fifth largest city in Côte d'Ivoire. Because of its geographical location situated in an arid area, the department of Korhogo is not as verdant as Soubré. Korhogo is the location of many agricultural projects focused

\footnotetext{
${ }^{4}$ The Bete constitute the vast majority of the indigenous population, followed by Bakoue and some Kouzié. Soubré is a prefecture and the capital of the new region of Nawa, born from the split of the former Bas-Sassandra. The department includes the subprefectures of Soubré, Liliyo, Oupoyo, Okrouyo, Buyo, Méagui and Grand Zattry.
} 
on increasing food security. In addition to visiting Korhogo, interviews were also carried out in Gbalogo, Gbaméleguekaha, Takalé and Natchokobadara.

During the visits to the two sites, the first author and the data collection team conducted a series of focus group discussions and individual interviews with farmers, labourers, truck drivers, traders, commission agents and commercial organizations (including food cooperatives) involved in the agricultural sector. The team conducted five focus group discussions with people involved in the food cooperatives that are central in the food production system. In addition, there were 51 individual interviews in two subprefectures and eight villages. In total, approximately 17 farmers and eight jardin were interviewed. The informants who were interviewed included both those with and without mobile phones. This allowed us to compare the situation of people in these two situations. The interview materials were transcribed and analysed.

With the exception of the investigation in Korhogo and Soubré markets, all the locations were rural village with populations ranging from 250 to 600 . All interviewees were over the age of 18 . None of the interviewees had more than a primary level of education. This was especially the case for women.

The farmers, truck drivers, wholesalers, retailers and resellers who were interviewed grew, transported and sold a wide variety of foodstuffs including rice, corn, bananas, cassava, yams, eggplants, okra, cabbage and pepper. Almost all farmers practised multiple cropping with cabbage being the most common crop. The household income of the farmers ranged from CFA 5,000 to CFA 850,000 (approximately USD 10 to USD 1,700) per month and the average household size was fewer than six people. The people associated with the cooperative have the highest income in this system ranging between CFA 180,000 and CFA 1,000,000 (approximately USD 365 to USD 2,000) per month. The interviewees in these two regions also had access to irrigation, but they noted that storage facilities and credit institutions were a problem. When considering the transportation workers and their equipment, the average age of trucks for food transportation is 13 years. Wholesalers and retailers make up the largest number of workers in this sector and are largely women (approximately $92 \%$ ). We found that $68 \%$ of interviewees working in the urban areas (Korhogo and Soubré) have at least one mobile phone with the capacity for two SIM cards.

Some interviewees in the region of Korhogo in rural areas refused to be recorded because they believed that some evil spirits could use their recorded voice for spell casting. In these cases, we transcribed the interviews on a notepad.

The following sections turn to the findings from the fieldwork, beginning with an overview of the food system before the advent of mobile phone in Côte d'Ivoire. We then report on how our interviewees perceived the effect of the mobile phone on their supply chain and economic activities. In conclusion, the factors that limit adoption of mobile phone by women in food supply system are discussed. 


\section{Findings and Discussion}

We will analyse the results by examining mobile phone use in the case of managing over and undersupply of goods by large-scale wholesalers, its use by what we call petit wholesalers and different food production systems where the use of mobile phone was not adopted for a variety of reasons. Our analysis indicates that the mobile phone has a different value depending on the position of the stakeholder. Below, we examine the production and marketing aspects of this perspective.

\subsection{Management of Logistics by Large-Scale Wholesalers}

As noted above, a central actor in Ivorian food production/marketing is the largescale wholesalers or cooperatives that can function as a cartel. These organizations often have an integrated position that includes contact with food producers (with whom they provide seeds and fertilizer), transportation workers who truck the products from the producers into the cities and the provision of a market space in the cities where retailers can order foodstuffs from the cooperative and then sell them to the consumers. These cooperatives have accounting services and a leader who is commonly chosen by the old women who have originally established the cooperative. As such, these cooperatives have a pivotal position in the Ivorian food production system.

While the "Chain of the Grandmother" system is firmly in place, it has been enhanced with the use of the mobile phone. This is reflected in the comments of Ngnan $^{5}$ Catherine, one of the elderly women who manage the cooperative:

My son, I'm glad you came to ask me that ... because it is we who have fed the Côte d'Ivoire. Even when there's been a crisis, we are dribbled the ball to send food to Abidjan

... It's not us that were going to Abidjan or in villages Soubré but these are our daughters. You see my daughter Zita, she is brave, she is like me and it is not the only one to do that way, to sell food products, and the other women of the cooperative also their daughters who are very involved in the production of food. In fact, they are over. You see it is not as a string. We moms, it was for us to feed Côte d'Ivoire and now they are our girls, yes it is the chain of Grandmother because we began, our daughters follow and their daughters will follow. But we are here to give advice. But now it has become even easier, it's true that the roads are not good but there's phone to call quickly, otherwise you had to pay before transporting someone to send message others producers. Ngnan Catherine (Market Soubré)

Informants such as Ngnan Catherine, a woman who managed the cooperative in Soubré, said that the mobile phone has revolutionized their work. They noted that they use the mobile phone to interact with truck drivers (sometimes as often as

\footnotetext{
${ }^{5}$ An honorific version of "Grandmother" in the local language.
} 
twice a day to each truck driver) to maintain an overview and manage the collection of food from producers. All the truck drivers interviewed in this study possessed and used mobile phones in their work. This was seen as an essential item. In the words of Konan, a driver:

My brother, if you do not have mobile today how you can do business. Today it has become necessary ... otherwise; women cooperatives cannot call you to pick up their goods. Without it, you lose money. Konan (Soubré Market)

Another driver, Vincent, also responded:

(He laughs)... I can say that with mobile phone, it is Money Horse Course, the money comes quickly ... Well I do not know how women were before but I think the phone mobile is important in the food trade and the phone companies have an incentive to cover all areas where there's a strong production that is otherwise difficult. Vincent (carrier) (Korhogo Market)

The women who run the cooperatives visit the producers to gauge whether there will be gluts or shortages of different crops. At the time of harvest, the actual surpluses and shortage become obvious, the women are able to call other cooperatives to either buy or sell particular crops as required. In some cases, this can be done before they are being transported into the cities.

In other cases, just as with Jensen's fishers (2007), there is the need to manage the transportation in real time. The women can divert trucks that are en route:

The phone today is important because you can call the driver while he is on his way to tell him to complete the inventory of goods ... before, if you had to start over ... it lost much of money. Communication is really important. "non fô lèhè" Kouyaté (Korhogo)

According to the women who manage the cooperatives, the mobile phone allows real-time ability to balance the distribution of crops.

There is another dimension to the marketing of foodstuffs in Côte d'Ivoire. There are one or more main markets managed by the cooperatives in the city. In these markets, there can be several hundred retailers who are active. The women who run these cooperatives ensure that there is enough but not too much of the different products in this location. In addition, there are also smaller street-side and local satellite markets that rely on the women running the larger markets. Where oversupply or undersupply of goods can happen in the main market, the same applies to these smaller markets. Again, the mobile phone allows a real-time ability to deal with these distribution problems.

The use of the mobile telephone is similar to that described by Jensen in India and the Peruvian sellers depicted by Barrantes Cáceres and Fernandez-Ardevol (2012). That is, the women running the cooperatives use the device to gather information and to address logistical issues more quickly than prior to the adoption of the mobile phone. Notably, however, the situation described here is from a somewhat different angle. With Jensen, Barrantes Cáceres and Fernandez-Ardevol, their analysis was from the perspective of the retailer, whereas this particular study focused more on the perspective of those managing the wholesale side of the equation. 


\subsection{Petit Wholesalers/Retailers}

Other groups that use the mobile phone to arrange logistics are the small (petit) wholesalers and the retailers. In the larger markets, there are some women who have a dual role. These petit wholesalers are retailers who have small sales outlets in one of the larger food cooperatives. Each retail outlet is about a few square metres in the market area (the land is often owned by the cooperative and rented to individuals). However, they are also small-scale entrepreneurs who, on a small scale, seek out alternative marketplace and supply systems. Rather than relying totally on the foodstuffs that are available through the cooperative, they seek out other types of foods from alternative producers that are transported to the market using noncooperative trucks. Similar to the managers of the cooperatives, these women described the mobile phone as an innovation in their job.

In their role as a petit wholesaler, they might use the phone to organize purchase of wares. They might negotiate with the producers about prices and organize the wares to be picked up and transported to the market with noncooperative trucks. Since their consignments might be smaller, these petit wholesalers might have to cooperate with other such wholesalers to share the cost of a truck. They may also have to arrange for the delivery of particular type of their foodstuff to the retailers in the satellite markets.

In their role as a retailer in the market, their interactions with the final users are face-to-face with no need for mediation. However, there are occasions where the retailers may need to quickly sell leftover produce. If the produce is highly perishable and there are not any storage possibilities, it is important for them to find other small retailers who will be able to quickly sell the surplus. The women must act quickly so as to not be caught with extra wares. The mobile phone becomes an important tool in this situation.

In this role, they become the buyer for another small satellite market that is not organized like the cooperative system. This position can lead to intense mobile phone use. This was perhaps more the case in Soubre than in Korhogo. There can be a series of calls early in the morning about the amount of produce transacted.

Based on these interactions, the retailers at the satellite markets will come to the main market to retrieve the bags of produce. There are also financial negotiations during such interactions:

In fact, I'm a relay for other markets. So, when I have many goods and products (that may) come to expire, I called the other traders, other markets so that they come to buy from me. It solves the problems of waste quickly... Monique

Like the large wholesalers running the big collectives, these petit wholesalers use the mobile phone when they have an excess or shortfall of foodstuffs. The mobile phone enables them to contact other producers and places quickly to either dump or buy a particular product. The material from the interviews indicates that there is a seasonal aspect to this issue. In the period after the rainy season, when there is an abundance of crops, the ability to buy or more often dispose of excess foodstuffs is important: 
After rainy season, we have many products on the market so you need to call other women in other markets they are taking it on credit or it may rot in our hand here. Yoboue Suzanne

In the case of managing the large cooperatives, the situation of the petit wholesalers and the case of the retailers, the mobile phone facilitates the logistics of food distribution by opening up the flow of information. The need for this varies according to the position of the stakeholder and in relation to the supply of various foodstuffs. It was also clear that such occurrence was more often evident in Korhogo than in Soubré.

\subsection{Non-use of Mobile Communication}

While the research shows that there were groups using mobile communication to facilitate the marketing of foodstuffs, it also presents groups which, for one reason or another, did not find the adoption useful.

\subsubsection{Jardin vs. Larger-Scale Production}

One group who made only limited use of mobile communication was women who had small "kitchen gardens" or jardin of approximately $10-20 \mathrm{~m}^{2}$ that were used to both provide food for the family and, when there was a surplus, to sell in the local market. This practice was more common in the areas near Korhogo. In the words of one informant:

... When you have a kitchen garden, it prevents you from hunger in the family. You plant what you want around your home and can prepare in your kitchen, you will cut it in the garden ... generally, it's not great but it helps a lot ... but when the rainy season it is great, we will sell what we could not eat in the market. Mariam

The concept of jardin appears often in the discourse of respondents. Informants note that they grow the tomato, pepper, carrot, eggplant, cabbage and others foodstuffs. However, when this production exceeds the needs of the home, the woman sells the surplus in the nearest market. Thus, the jardin becomes an economic opportunity for women. The revenues obtained from the selling of the jardin products range approximately USD 10-25 per day of sales. This cash becomes a fund with which these women can purchase small things for the home and for their children. This income may also become a point of contest between the husband and wife. According to the women interviewed, if the husband is aware of the income, he may withhold other monies from the wife and family. Conversely, nearly all the women noted that they sometimes help their husband monetarily with these revenues:

... When my husband needs money to pay for the children education or farm products of maintenance, and he has no money, I lend him money (that) comes from sales of products of my Jardin. Mariam 
As one might expect, the interaction between the woman and the market is very informal. Mobile phone is not used extensively in this context nor were there many of these informants who actually owed a phone. Of the 17 producers interviewed in this analysis, eight fell into this category. In general, these producers grew less than $250 \mathrm{~kg}$ of produce per year. ${ }^{6}$ They were also the least likely to have a mobile phone. Only three of the eight interviewees owned one. Furthermore, as opposed to the reported use of larger producers, these women did not use their phones for business purposes. ${ }^{7}$ Familial interaction was often the main motivation for owning a phone. The informants noted that mobile telephony was used to facilitate logistics and to save time in organizing activities.

Our finding indicates that it was only the larger producers who used the mobile phone in the line of work to interact with the truck drivers, retailers and wholesalers. The smaller producers noted that they found it easiest to accept bids for produce face-to-face. The informants felt that it was too complicated to carry out these negotiations via the mobile phone. There are well-established meeting points when the producers and wholesalers can meet to negotiate the prices and quantities of goods. In these situations, there is a legacy of trust and also well-established routines that augur against use of the mobile phone:

The prices here are the result of markets. But usually it is the amount that determines it. But when the distance is too great and the producer knows you, you can negotiate by phone if not in this environment benefit goes more to meetings as in the old time.... non fô lèhè Kouyaté (Korhogo)

That said, when the producer interacted with a single wholesaler, the use of the mobile phone was more obvious. The mobile phone was used to agree on the logistics of delivering the food from the farm to the market. This type of interaction was more common among the larger producers when they are selling to the large cooperatives.

\subsubsection{Effect of the Distance to Market}

Another element that limits the usefulness of the mobile phone is when the market is located near the farm. If the distance is great, then the farmer will need to work out a plan to transport the goods by, for example, contacting a truck driver. However, where the proximity is close, the farmer can carry the wares to the market, either on her head or in a cart, without a need for a mobile phone. In the rural areas where the

\footnotetext{
${ }^{6}$ The categorization of the producers is based on the quantity of crops produced and not the area of production. The quantity of products produced is a more reliable measure since some producers have a large area but only have a small output. Thus, there is often not a high correlation between the area of a farm and its production.

${ }^{7}$ In the case of medium-scale producers who grew between 250 and $1,000 \mathrm{~kg}$ of produce, five out of six had a mobile phone, and among the three large-scale producers, two of them owned a mobile phone.
} 
roads are in poor conditions, it is difficult to contract a truck to come to retrieve a small consignment of, for example, $5-100 \mathrm{~kg}$.

While proximity to the market might suggest that an individual can forego use of the mobile phone, there is also an issue of safety. Our informants shared that there is the question of highway robbers who prey on women moving their wares to market. In this case, the mobile phone is seen as a security link. In the words of Akissi:

Here, There are too many highway robbers... in fact it is the demobilized (military) men ... become armed robbers, they know we poor women, we are no force, they attack to rob us. I remember there's my cousin who went to meet Adjoua producing credits to pay for his goods 630,000 CFA. (She) was stripped. She even had the opportunity otherwise, they would rape her. Fortunately, the area was covered by the MTN (mobile phone) network, so she was able to call his brother in town who came to fetch her. Mobile, it helps us ... Akissi.

The ability to transport crops to nearby markets means that the individual does not need to arrange other forms of transportation and thus does not need to use a mobile phone. However, there is safety and security associated with having a device.

\subsubsection{African Taboo and Mistrust of the Technology}

The concept of "African taboo" plays on the idea that ownership and use of a mobile phone can lead to jealousy and mistrust. Since a mobile phone is a sign of wealth, in some situations, it can arouse jealousy from the other members of the community. Therefore, it is best not to "flash" a mobile phone. In the words of one informant Soro Kolo: "It is better to live hidden if you want to live long time".

Another issue is that the use of the mobile phone engenders a fear of technological systems that in turn leads to a reluctance to adopt. In the words of Silué:

Portable (a mobile phone) is good ... but when you know what is behind, you're not even going to buy (one). Wizards move quickly inside, and then they can quickly know where you are ... so around here I tell the people of my family not to pay it.

A number of the informants who had not used the mobile phone reported having a relative that went mad after receiving a call on their mobile phone starting with the number +223 . When asked how this madness manifests, one informant, Konate Djafolon, said of her husband, "he speaks alone all the night long". Another informant, Miriam, noted that it was the light function of the mobile phone that disturbed the spiritual world:

Since Lacina got mobile phone, he is always getting sick ... he says that someone that he did not know just called his number and then hung up; when we went to look for his illness there, the healer said that the spirits are angry against him because every night when they come to see him... he turns the light of his cell phone and it bothers them, so that's why they hit him.

The discussion of these taboos is more common among those in the rural areas. As noted above, it is also in these areas that there is the least functional value for the mobile phone. There are often well-established alternative methods that allow people to avoid use of the device. 


\section{Conclusion}

We have examined how the mobile phone effects (or alternatively, does not affect) food distribution systems in Côte d'Ivoire. In the case of large-scale wholesalers who manage the food cooperatives, the mobile phone plays role in allowing the women who run these organizations to "fine-tune" the transport of wares when there are surpluses and shortages. The managers of the cooperatives can buy or sell products while they are being transported. We find that the mobile phone was used by petit wholesalers in a similar way. However, they also use the device to organize their somewhat more scattered distribution chain and to interact with other smallscale wholesalers to collaborate on transportation. The informants clearly see that the device helps to facilitate logistics. Lastly, it allows the retailers to avoid holding on to too much perishable foodstuffs.

On the other side of the equation, there are those who are less attuned to mobile communication in the production of food. We find that some smaller producers in the more rural areas do not use the mobile phone since there are alternative systems of organizing the distribution chain that, to some degree, preclude the need for its use. In addition, there are those who live so near the market that there is no need to use the mobile phone to arrange for logistics. There is also a sense among some of the informants that the mobile phone is a source of bad spirits.

Overall, these findings fit into other work that has examined the role of information flow in rural areas. Looking at the people who have adopted the use of mobile phone, their usage provides efficiency and robustness to the distribution system that was not possible before (Clark 1995). As noted by Argenti (1997), the mobile phone is an important element in the development of food security.

Mobile communication improves the flow of real-time information that allow the food sector, or for that matter, any entrepreneurial activity, to function better (Jagun et al. 2008). Because of this, they supplement existing systems of interaction and improve the efficiency of these systems. In addition, they reduce various types of embezzlement (Porter 2012).

It is interesting to note that the mobile phone system was not used to any degree for the transfer of monies. In other countries, mobile phones have gained a central role with which people transfer money for purchases (Hughes and Lonie 2007). This can be partially explained by the existence of well-established banking flows in the case of large-scale wholesalers and the selective use of mobile phones among the smaller producers. Notably, such money transfer system was not utilized by the petit wholesalers. It is possible that this particularly entrepreneurial group could lead the way in the use of this type of application. However, if there is no critical mass of users, it may be difficult to institutionalize use (Ling and Canright 2013).

Another element that may retard the use of mobile communication in food distribution is the cartel-like structure of the large food cooperatives (Harre 2001). The markets are run like cartels that control the access to market space and deter other actors from penetrating the market. This can both facilitate food production and limit innovation. To the degree that alternative supply chains that are perhaps 
based on the use of ICTs are frustrated by the existing cartel-like structure of the marketing chains, there will not be innovation. The tradition-bound "Chain of the Grand Mother" is a well-functioning system that facilitates distribution for retailers who are illiterate and want to conduct their daily business. That said, it also hinders the motivation to adopt new technologies such as mobile phone and mobile payment.

Another issue here is the taboos and mistrusts associated with mobile communication. These were largely prevalent in the rural areas. It is interesting to note that their social position resulted in a type of anti-mobile ideology (Ling 2012). This helped them to justify their situation vis-à-vis the mobile phone. An ideology of use, or in this case non-use, is often central to our relationship to technology. In this case, it seems that the informants had constructed a series of rationales regarding this anti-mobile ideology.

It is clear that there are limitations to this work. We have only been able to interview people in two sections of Côte d'Ivoire. There are likely other dimensions to the use of the mobile phone that were not uncovered in this analysis. Nonetheless, these insights help us to understand the ways in which the use of mobile phone influences pre-existing systems of distribution.

Finally, this study recommends that training in local languages should be conducted by private companies, especially mobile telephone service providers and interested development agencies. This is to enable essential improvement in accessing mobile telephone services by rural farmers, especially the women in Côte d'Ivoire. Consequently, the mobile phone would be a boon, especially for them to send e-moneys because it seems secured. Due to the bad condition of roads which impedes transportation via trucks, they are forced to walk short distances with their produce to speak directly to wholesalers and cooperatives to sell their goods. They admit that this approach is exhausting, but it avoids heavy financial burdens, e.g. transportation charges and physical efforts to find coverage area of the mobile network.

Open Access This chapter is distributed under the terms of the Creative Commons Attribution Noncommercial License, which permits any noncommercial use, distribution, and reproduction in any medium, provided the original author(s) and source are credited.

\section{References}

Abraham, R. (2006). Mobile phones and economic development: Evidence from the fishing industry in India. International conference on Information and Communication Technologies and Development, 2006 (ICTD'06), Barkeley, CA (pp. 48-56).

Aker, J. (2008). Does digital divide or provide? The impact of cell phones on grain markets in Niger (Center for Global Development Working Paper No. 154). Retrieved from http://papers. ssrn.com/sol3/papers.cfm?abstract_id=1093374

Argenti, O. (1997). Approvisionnement et distribution alimentaire des villes de l'Afrique Francophone. In Seminaire Sous regional FAO-ISRA. Presented at the Seminaire Sous regional FAO-ISRA. Dakar: FAO. 
Asenso-Okyere, K., \& Ayalew Mekonnen, D. (2012). The importance of ICTs in the provision of information for improving agricultural productivity and rural incomes in Africa (UNDP Working Paper). http://web.undp.org/africa/knowledge/WP-2012-015-okyere-mekonnen-ictproductivity.pdf

Barrantes Cáceres, R., \& Fernandez-Ardevol, M. (2012). Mobile phone use among market traders at fairs in rural Peru. Information Technologies and International Development, 8(3), 35-52.

Bayes, A. (2001). Infrastructure and rural development: Insights from a Grameen Bank village phone initiative in Bangladesh $\star$. Agricultural Economics, 25(2-3), 261-272.

Beuermann, D. W., McKelvey, C., \& Sotelo, C. (2012). The effects of mobile phone infrastructure: Evidence from rural Peru. Retrieved from http://www.aae.wisc.edu/mwiedc/papers/2011/ Beuermann_Deither.pdf

Chaléard, J.-L. (1996). Temps des villes, temps des vivres: l'essor du vivrier marchand en Côte d'Ivoire. KARTHALA Editions. Retrieved from http://books.google. com/books?hl=en\&lr=\&id=bFMPBWQJq3cC\&oi=fnd\&pg=PA5\&dq=Temps+des+ villes,+temps+des+vivres:+1\%27essor+du+vivrier+marchand\&ots=JRRhyBEi4D\&sig= PmMG9tf1xENDzXE0GRZPApgqT0s

Chib, A., \& Hsueh-Hua Chen, V. (2011). Midwives with mobiles: A dialectical perspective on gender arising from technology introduction in rural Indonesia. New Media and Society, 13.

Clark, G. (1995). Onions are my husband: Survival and accumulation by West African market women (1st ed.). Chicago: University of Chicago Press.

Cohen, A., Lemish, D., \& Schejter, A. M. (2007). The wonder phone in the land of miracles: Mobile telephony in Israel. Cresskill: Hampton Press.

Courade, G. (1985). Villes/campagnes: Les liaisons dangereuses. In N. Bricas et al. (Eds.), Nourrir la ville en Afrique subsaharienne (pp. 67-81). Paris: L'Harmattan.

Donner, J. (2008). Research approaches to mobile use in the developing world: A review of the literature. The Information Society, 24(3), 140-159.

FAO. (1996). Déclaration de Rome sur la sécurité alimentaire mondiale et Plan d'action du sommet mondial de l'alimentation, rapport du sommet mondial de l'alimentation 13-17. Rome: FAO.

Fernandez-Ardevol, M., Barrantes Cáceres, R., \& García, A. A. (2011). Mobile telephony in a rural areas:a case. In Todos tienen celular (WP, 161., Serie Economía, pp. 50-60). Lima: Instituto de Estudios Peruanos.

Fischer, C. (1992). America calling: A social history of the telephone to 1940. Berkeley: University of California.

Flor, A. G. (2009). Developing societies in the information age: A critical perspective. Quezon City: UP Open University.

Gakuru, M., Winters, K., \& Stepman, F. (2009). An inventory of innovative farmer advisory services. Accra: Agricultural Research in Africa (FARA).

Goosens, F., Minten, B., \& Tollens, E. (1994). Nourrir Kinshasa: L'approvisionnement local d'une métropole africaine. Paris: L'Harmattan.

Hafkin, N. J., \& Odame, H. H. (2007). Gender, ICTs and agriculture. A situation analysis for the 5th consultative expert meeting of CTA's ICT observatory meeting on Gender and Agriculture in the Information Society, Sageningen.

Harre, D. M. (2001). Formes et innovations organisationnelles du grand commerce alimentaire à Abidjan, Côte-d'lvoire. Autrepart, 3, 115-132.

Hughes, N., \& Lonie, S. (2007). M-PESA: Mobile money for the "unbanked" turning cellphones into 24-hour tellers in Kenya. Innovations Technology Governance Globalization, 2(1-2), 63 81.

Jagun, A., Heeks, R., \& Whalley, J. (2008). The impact of mobile telephony on developing country micro-enterprise: A nigerian case study. Information Technologies and International Development, 4(4), 47-65.

Jensen, R. (2007). The digital provide: Information (technology), market performance and welfare in the South Indian fisheries sector. The Quarterly Journal of Economics, 122(3), 879-924. 
Johnson, D. G. (2004). Ethical, psychological and societal problems of the application of ICTs in education. Moscou: UNESCO Institute for Information Technologies in Education (IITE).

Ling, R. (2012). Taken for grantedness: The embedding of mobile communication into society. Cambridge, MA: MIT Press.

Ling, R., \& Canright, G. (2013). Perceived critical adoption transitions and technologies of social mediation. Cell and Self conference, Ann Arbor

Molony, T. (2006). "I don't trust the phone; It always lies": Trust and information and communication technologies in Tanzanian micro-and small enterprises. Information Technologies and International Development, 3(4), 67-83.

Overå, R. (2006). Networks, distance, and trust: Telecommunications development and changing trading practices in Ghana. World Development, 34(7), 1301-1315.

Porter, G. (2012). Mobile phones, livelihoods and the poor in Sub-Saharan Africa: Review and prospect. Geography Compass, 6(5), 241-259. doi:10.1111/j.1749-8198.2012.00484.x.

Prahalad, C. K., \& Hammond, A. (2002). Serving the world's poor, profitably. Harvard Business Review, 80(9), 48-59.

Rahman, T. (2007). "Real markets" in rural Bangladesh: Institutions, market interactions and the reproduction of inequality. Manchester: IPPG, University of Manchester.

Rashid, A. T., \& Elder, L. (2009). Mobile phones and development: An analysis of IDRC-supported projects. The Electronic Journal of Information Systems in Developing Countries, 36(2), 1-16.

Sauvé, L., \& Machabée, L. (2000). La représentation: Point focal de l'apprentissage. Éducation relative à l'environnement-Regards Recherches Réflexions, 2, 175-185.

Souter, D., Scott, D., Garforth, C., Jain, R., Mascarenhas, O., \& McKemey, K. (2005). The economic impact of telecommunications on rural livelihoods and poverty reduction. Reading: Gamos. Retrieved from http://gamos.org.uk/KaR8347Summary.pdf

World Bank. (2012). Information and communications for development 2012: Maximizing mobile. Washington, DC: International Bank for Reconstruction and Development/The World Bank. 